Syntax Literate : Jurnal Ilmiah Indonesia p-ISSN: 2541-0849

e-ISSN : 2548-1398

Vol. 6, Special Issue No. 2, Desember 2021

\title{
KEBIJAKAN DAN IMPLEMENTASI PENYERAHAN PRASARANA, SARANA, DAN UTILITAS UMUM PERUMAHAN DI KABUPATEN PAMEKASAN
}

\author{
Dandy Himawan Sutanto \\ Magister Sains Hukum dan Pembangunan SPS Universitas Airlangga, Surabaya, \\ Indonesia \\ Email: dandy.himawan.sutanto-2019@pasca.unair.ac.id
}

\begin{abstract}
Abstrak
Prasarana, Sarana dan Utilitas Umum Perumahan (PSU) merupakan hak yang harus dipenuhi oleh pengembang perumahan agar lingkungannya layak untuk menjadi hunian. Sementara ini masih banyak kalangan masyarakat terutama calon pembeli perumahan tidak mengetahui haknya tersebut. Oleh karena itu peran pemerintah perlu mengatur kebijakan pengelolaan PSU perumahan agar terjadi keseimbangan antara hak yang harus diperoleh calon penghuni pada khususnya dan masyarakat sekitar pada umumnya dengan kewajiban yang harus dipenuhi oleh pengembang. Pemerintah Daerah selaku pelaksana mandat dari institusi diatasnya maka perlu kepekaan untuk menjawab tantangan tersebut karena pertumbuhan penduduk akan selalu bertambah dan tentunya kebutuhan rumah tinggal akan terus bertambah sedangkan luas lahan yang ada cenderung tetap. Untuk pemecahan masalah tersebut maka peneliti menggunakan metode pendekatan sosio legal yaitu tetap mengacu kepada pendekatan hukum dan studi kasus. Sehingga diperoleh hasil bahwa guna mewujudkan penyediaan prasarana, sarana dan utilitas umum perumahan di Kabupaten Pamekasan telah dibentuk Peraturan Daerah Nomor 7 tahun 2014 tentang Penyerahan Prasarana, Sarana, dan Utilitas Perumahan dan Permukiman.
\end{abstract}

Kata Kunci: prasarana, sarana, utilitas, pengembang, pemerintah.

Infrastructure, Facilities and Public Housing Utilities (PSU) is a right that must be fulfilled by housing developers so that the environment is suitable to become residential. Meanwhile, there are still many people, especially prospective housing buyers, do not know their rights. Therefore, the role of the government needs to regulate the management policy of housing PSU in order for a balance between the rights that must be obtained by prospective residents in particular and the surrounding community in general with obligations that must be met by developers. The Local Government as implementing the mandate of the above institutions need sensitivity to answer these challenges because population growth will always increase and of course the need for housing will continue to grow while the existing land area tends to remain. For the mass solution, researchers use a method of socio-legal approach that still refers to legal approaches and case studies. So that the results obtained that in order to realizing the provision of infrastructure, facilities and public housing utilities in Pamekasan Regency has been established Regional Regulation \#7 of 2014 on the Delivery of Infrastructure, Facilities, and Housing and Settlement Utilities.

Keywords: infrastructure, facilities, utilities, developers, government.

$\begin{array}{ll}\text { How to cite: } & \text { Sutanto. D. H (2021) Kebijakan dan Implementasi Penyerahan Prasarana, Sarana, dan Utilitas Umum } \\ & \text { Perumahan di Kabupaten Pamekasan, Syntax Literate: Jurnal Ilmiah Indonesia 6(2) } \\ \text { E-ISSN: } & \text { 2548-1398 } \\ \text { Published by: } & \text { Ridwan Institute }\end{array}$


Received: 2021-10-20; Accepted: 2021-11-05; Published: 2021-11-20

\section{Pendahuluan}

Laju pertumbuhan penduduk Kabupaten Pamekasan dalam kurun waktu tahun 2010 sampai dengan 2020 adalah rata-rata sebesar 0,66 \%. Dengan pertumbuhan penduduk paling tinggi berada di kecamatan pegantenan sebesar 1,58 \%, disusul selanjutnya kecamatan proppo sebesar 1,23 \%, kecamatan Pasean 1,10\%.

Berdasarkan data yang dirilis oleh BPS kabupaten Pamekasan melalui sensus penduduk tahun 2020 diketahui jumlah penduduk Kabupaten Pamekasan adalah sebesar 850.057 jiwa dengan komposisi penduduk laki-laki sebesar 416.961 jiwa $(49,05 \%)$ dan penduduk perempuan sebesar 433.096 jiwa (50,95\%) . Rasio Jenis kelamin Kabupaten Pamekasan tahun 2020 sebesar 96,27 \%, yaitu dalam 100 penduduk perempuan terdapat 96 sampai dengan 97 penduduk laki-laki. Dengan kepadatan penduduk di Kabupaten Pamekasan mencapai 1.072,99 jiwa/Km.

Sementara itu jumlah rumah yang ada di kabupaten Pamekasan jika dikonversi atau dianggap sama dengan jumlah pelanggan menurut jenis pengguna hunian berdasarkan data BPS tahun 2021 hasil sensus 2020 diketahui sebanyak 214.763 rumah tangga. Dengan komposisi sebaran di kecamatan Palengaan sebanyak 29.016 rumah tangga, kecamatan Pademawu sebanyak 27.401 rumah tangga, kecamatan Pasean sebanyak 19.106 rumah tangga, kecamatan Pamekasan sebanyak 28.804 rumah tangga, kecamatan Kadur sebanyak 16.663 rumah tangga, kecamatan Tlanakan sebanyak 19.359 rumah tangga, kecamatan Waru sebanyak 20.749 rumah tangga, kecamatan Pegantenan sebanyak 24.102 rumah tangga, kecamatan Pakong sebanyak 11.988 rumah tangga, kecamatan Batumarmar sebanyak 28.983 rumah tangga, kecamatan Proppo sebanyak 28.450 rumah tangga, kecamatan Galis sebanyak 9.817 rumah tangga , dan kecamatan Larangan sebanyak 18.586 rumah tangga.

Disamping itu pemerintah kabupaten Pamekasan memiliki rencana untuk menetapkan luas lahan pertanian pangan berkelanjutan (LP2B).

Dari komposisi data laju pertumbuhan penduduk kabupaten Pamekasan dan jumlah rumah berdasarkan sambungan listrik PLN untuk rumah tangga tentunya perlu dibuat kebijakan pemerintah kabupaten pamekasan berkaitan penyelenggaran perumahan. Dalam penyelenggaraan perumahan ini tentunya sudah harus memuat kebijakan tentang pasarana, sarana dan utililtas umum baik yang diselenggrakan oleh pemerintah daerah dan/atau setiap orang untuk menjamin hak setiap warga negara untuk menempati, menikmati, dan/atau memiliki rumah yang layak dalam lingkungan yang sehat, aman, serasi, dan teratur.

Berdasarkan Undang-Undang Nomor 23 tahun 2014 tentang Pemerintahan Daerah, pada pasal 12 disebutkan bahwa perumahan dan kawasan permukiman termasuk dalam salah satu urusan pemerintahan wajib yang berkaitan dengan pelayanan dasar sehingga kewenangan pemerintah kabupaten/kota dalam hal pembagian urusan pemerintahan bidang perumahan dan kawasan permukiman berkewajiban untuk 
melaksanakan sub urusan penyelenggaraan Prasarana, Sarana, dan Utilitas Umum (PSU) perumahan. Sedangkan PSU untuk kawasan permukiman merupakan kewenangan kewenangan pemerintahan daerah provinsi. PSU sebagai bagian penting yang tidak terpisahkan dalam perumahan, namun sering terabaikan baik oleh calon penghuni perumahan maupun oleh pengembang. Praktik jual beli tanah kaveling bahkan perumahan masih cenderung liar karena proses penyediaan tanah untuk perumahan banyak yang dilakukan tanpa mendapatkan pengesahan rencana tapak (siteplan) dari Pemerintah Daerah melalui dinas teknis yang menangani tentang perumahan dan kawasan permukiman terlebih dahulu.

Oleh sebab itu peran pemerintah daerah kabupaten/kota dan harus didukung oleh pemerintah pusat terutaman BPN/ATR kabupaten/kota bersinergi untuk mengawal penyelenggaraan perumahan dalam hal kebijakan penyediaan dan pengelolaan PSU yang dilaksanakana oleh pihak swasta, BUMN dan BUMD harus memenuhi ketentuan umum dan sesuai dengan standar teknis yang berlaku.

Mengingat pentingnya hal tersebut bagi keberlangsungan hidup manusia, maka pada tangal 7-18 Agustus 2000 dalam Sidang Tahunan MPR dilakukan Amandemen Kedua UUD 1945 yang salah satu perubahan tersebut terdapat pada pasal $28 \mathrm{H}$ ayat 1 : "Setiap orang berhak hidup sejahtera lahir dan batin, bertempat tinggal, dan mendapatkan lingkungan hidup yang baik dan sehat serta berhak memperoleh pelayanan kesehatan".

Dari kutipan pasal $28 \mathrm{H}$ ayat 1 tersebut di atas ada empat hal penting yang diamanatkan salah satunya, yaitu mendapatkan lingkungan hidup yang baik dan sehat. Hal ini berarti lingkungan yang baik dan sehat merupakan tanggung jawab pemerintah dan pemerintah daerah yang dapat dilakukan melalui kebijakan manajemen PSU mulai dalam perencanaan, penyediaan, pembangunan, pengelolaan, serah terima dan pemanfaatan baik oleh pengembang swasta maupun oleh pengembang BUMN/Pemerintah.

Dalam dokumen Rencana Pembangunan dan Pengembangan Perumahan dan Kawasan Permukiman (RP3KP) yang dimiliki Pemerintah Kabupaten Pamekasan melalui Dinas Perumahan Rakyat dan Kawasan Permukiman memiliki visi "Terpenuhinya kebutuhan rumah layak huni, berkelanjutan, berbudaya, dan terjangkau yang didukung oleh prasarana, sarana, dan utilitas yang memadai secara merata bagi masyarakat Kabupaten Pamekasan”. Dokumen tersebut sebagai salah satu bagian kebijakan pemerintah Kabupaten Pamekasan untuk mewujudkan implementasi regulasi yang diterbitkan melalui Peraturan Daerah Nomor 7 tahun 2014 tentang Penyerahan Prasarana, Sarana, dan Utilitas Perumahan dan Permukiman. Sedangkan pada kenyataannya, bahasa dalam aturan seperti peraturan daerah masih bersifat umum sehingga butuh aturan yang lebih teknis berupa peraturan Bupati untuk menjalankan peraturan tersebut sebagai bentuk mandat dari aturan di atasnya. Secara umum penyebab dari permasalahan PSU itu adalah belum cukupnya peraturan yang mengatur penyelenggaraan PSU, di samping itu minimnya komitmen dan kontrol dalam kebijakan dan pelaksanaan perencanaan, penyediaan, pengaturan pembangunan (standar 
teknis/konstruksi), penyerahterimaan dari pengembang ke pemerintah, pengelolaanpengelolaan, dan pemanfaatan.

Jumlah penduduk Kabupaten Pamekasan berdasarkan data BPS yang dipublikasi melalui Pamekasan dalam angka tahun 2021 dapat dilihat pada Tabel 1

\section{Tabel 1}

Jumlah Penduduk tiap kecamatan di Pamekasan

\begin{tabular}{llll}
\hline No & $\begin{array}{c}\text { Nama } \\
\text { Kecamatan }\end{array}$ & $\begin{array}{c}\text { Jumlah } \\
\text { Penduduk }\end{array}$ & $\begin{array}{c}\text { Luas } \\
\text { Wilayah }\end{array}$ \\
\hline 1 & Tlanakan & 64.122 jiwa & $4.810 \mathrm{Ha}$ \\
\hline 2 & Pademawu & 84.803 jiwa & $7.189 \mathrm{Ha}$ \\
\hline 3 & Pamekasan & 89.017 jiwa & $2.647 \mathrm{Ha}$ \\
\hline 4 & Proppo & 84.864 jiwa & $7.149 \mathrm{Ha}$ \\
\hline 5 & Palengaan & 82.600 jiwa & $8.848 \mathrm{Ha}$ \\
\hline 6 & Galis & 29.770 jiwa & $3.186 \mathrm{Ha}$ \\
\hline 7 & Larangan & 56.553 jiwa & $4.086 \mathrm{Ha}$ \\
\hline 8 & Kadur & 47.959 jiwa & $3.071 \mathrm{Ha}$ \\
\hline 9 & Pegantenan & 73.686 jiwa & $8.604 \mathrm{Ha}$ \\
\hline 10 & Pakong & 36.817 jiwa & $5.242 \mathrm{Ha}$ \\
\hline 11 & Waru & 64.394 jiwa & $7.003 \mathrm{Ha}$ \\
\hline 12 & Pasean & 55.853 jiwa & $7.688 \mathrm{Ha}$ \\
\hline 13 & Batumarmar & 79.519 jiwa & $9.707 \mathrm{Ha}$ \\
\hline \multicolumn{4}{l}{ Sumber: Badan Pusat Statistik tahun 2020}
\end{tabular}

Dari tabel di atas diketahui bahwa Kecamatan Pamekasan merupakan wilayah paling kecil namun jumlah penduduknya paling besar. Dengan komposisi sebaran penduduk seperti pada gambar tentunya akan mempengaruhi pola tata ruang, agar terjadi pemerataan dan keseimbangan tata guna lahan maka perlu kehadiran pemerintah untuk membuat kebijakan yang dapat diimplementasikan baik jangka pendek, menengah dan panjang.

Rumusan kebijakan jangka pendek tersebut dapat dilakukan melalui metode analisis Brainstorming. Brainstorming dapat digunakan untuk mengasilkan sejumlah perkiraan mengenai solusi-solusi yang potensial bagi berbagai permasalahan, brainstorming meliputi beberapa prosedur yaitu:

a. Kelompok-kelompok brainstorming harus disusun sesuai dengan sifat masalah yang diinvestigasi, hal ini biasanya berarti seleksi orang-orang yang sangat mengetahui kondisi yang ada yaitu para ahli.

b. Proses pemunculan ide dan harus benar-benar terpisah karena diskusi kelompok yang intensif dapat dirintangi oleh kritik dan debat yang prematur.

c. Suasana aktivitas-aktivitas brainstorming harus sedapat mungkin dijaga tetap terbuka dan permisif selama tahap pemunculan ide.

d. Fase evaluasi ide harus dimulai hanya setelah semua ide dimunculkan, artinya fase pertama telah tuntas.

Sedangkan rumusan kebijakan jangka panjang termaktub dalam visi strategis, para 
pimpinan dan masyarakat memiliki perspektif yang luas dan jangka panjang tentang penyelenggaraan pemerintahan yang baik dan pembangunan manusia bersama dengan dirasakannya kebutuhan untuk pembangunan tersebut.

Berdasarkan dari uraian latar belakang di atas maka penulis melakukan suatu penelitian yang berkaitan terhadap analisis implementasi dengan peraturan perundangundangan berkaitan tentang Prasarana, Sarana dan Utilitas Umum Perumahan Komersial, terkait isu hukum yang akan dibahas dan merumuskan argumentasi hukum baru berkaitan dengan peraturan perundang-undangan di kabupaten Pamekasan yang mengatur mengenai kebijakan dan implementasi pengelolaan (Hayati, 2021). Prasarana, Sarana dan Utilitas Umum untuk pelaksanaan dari UU ini diperlukan pengaturan lebih lanjut pada peraturan perundang-undangan di bawahnya, dari Peraturan Pemerintah sampai Peraturan Daerah Provinsi maupun Peraturan Daerah Kabupaten/Kota. Dewasa ini baru beberapa daerah yang aktif mengimplementasikan Undang-Undang Nomor 1 Tahun 2011 dengan mengeluarkan beberapa Peraturan Daerah. Peraturan Daerah diperlukan untuk mendukung secara legal dan formal pengaturan teknis pelaksanaan dan tindak lanjut di lapangan. Misalnya Peraturan Daerah yang mengatur secara ketat penyerahan Prasarana, Sarana dan Utilitas Umum Perumahan dan Permukiman. Dengan adanya peraturan yang mengatur hingga masalah teknis tersebut, keberlanjutan pemeliharaan fasilitas umum (fasum) dan fasilitas sosial (fasos) dapat tetap terjaga dan penyimpangan penggunaan lahan fasum dan fasos tersebut semakin kecil dan secara tidak langsung berkontribusi dalam mewujudkan lingkungan hunian yang layak secara Nasional.

Oleh karena itu, berdasarkan penelusuran awal banyak hal yang terindikasi sebagai penyebab terhambatnya proses penyediaan dan pengelolaan PSU perumahan. Dengan melihat pada permasalahan di atas, maka pertanyaan yang ingin dijawab melalui penelitian ini yaitu:

a. Bagaimana pengaturan penyediaan PSU perumahan, untuk rumah komersial di Kabupaten Pamekasan saat ini?

b. Bagaimana implementasi serah terima PSU perumahan dari pengembang ke pemerintah daerah, untuk rumah komersial di Kabupaten Pamekasan?

\section{Metode Penelitian}

Dalam mencari pemecahan terhadap permasalah yang akan dibahas melalui penelitian ini, maka pendekatan masalah yang akan digunakan adalah pendekatan sosiolegal. Dengan pendekatan masalah tersebut diharapkan dapat menggali penyebab masalah lebih dalam melalui berbagai aspek keilmuan. Pendekatan sosio-legal merupakan pendekatan interdisipliner. Tujuannya adalah menggabungkan segala aspek perspektif.

Pendekatan sosio legal tersebut tetap mengacu kepada pendekatan hukum (satute approach) dan pendekatan studi kasus (case study). Karena pendekatan yang demikian, tujuan sosio-legal adalah secara lengkap mengombinasikan pengetahuan, keterampilanketerampilan, dan bentuk-bentuk pengalaman penelitian dari dua atau beberapa disiplin 
dalam suatu upaya untuk mengatasi beberapa keterbatasan teoritis dan metodologis dari disiplin ilmu yang bersangkutan dan menciptakan landasan untuk mengembangkan suatu bentuk baru dari analisis.

\section{Pembahasan}

Perkembangan pembangunan perumahan baik rumah umum maupun komersil di Kabupaten Pamekasan akhir-akhir ini sangat pesat. Dalam rangka menyelaraskan perkembangan tersebut perlu langkah kongkret kebijakan guna mewujudkan kawasan perumahan yang sesuai dengan standar teknis berdasarkan cakupan layanan bagi penghuni perumahan. Dalam penelitian ini, penulis mengangkat tentang permasalahan kebijakan dan implementasi pengelolaan berkaitan penyediaan Prasarana, Sarana dan Utilitias umum (PSU) khusus perumahan komersil di Kabupaten Pamekasan yang berkaitan dengan segala pihak terkait.

Pembahasan hanya yang berkaitan dengan penyediaan prasarana, sarana dan utilitas umum perumahan jenis rumah komersial berbentuk rumah deret dan implementasi penyerahan prasarana, sarana dan utilitas umum perumahan karena di dalam rencana strategis (renstra) Kabupaten Pamekasan tahun 2018 sampai dengan tahun 2023 mendatang direncanakan target capaian kinerja program adalah masih pendataan rumah sewa milik masyarakat, rumah susun dan rumah khusus sebanyak 2 kecamatan di tahun 2022 dan 7 kecamatan di tahun 2023.

\section{Kebijakan Penyediaan Prasarana, Sarana dan Utilitas Umum Perumahan}

Penyediaan Prasarana, Sarana dan Utilitas umum perumahan berupa kelengkapan fisik untuk mendukung terwujudnya perumahan yang sehat, aman dan terjangkau. Dengan demikian ketersediaan prasarana, sarana, dan utilitas umum merupakan kelengkapan dan bagian yang tidak terpisahkan dari upaya pengembangan perumahan dan kawasan permukiman. Oleh sebab itu salah satu ketentuan yang harus dipenuhi oleh pengembang dalam perjanjian pendahuluan jual beli harus sudah memuat ketersediaan prasarana, sarana dan utilitas umum yang sesuai dengan standar teknis dengan memperhitungkan kesesuaian antara kapasitas pelayanan dan jumlah rumah serta keterpaduan antara prasarana, sarana, dan utilitas umum dan lingkungan hunian karena dalam Undang-Undang No. 1 tahun 2011 tentang perumahan dan kawasan permukiman yang dimaksud dengan penyelenggaraan perumahan adalah;

a. perencanaan perumahan;

b. pembangunan perumahan;

c. pemanfaatan perumahan; dan

d. pengendalian perumahan

Perumahan sebagaimana dimaksud di atas meliputi rumah tunggal maupun rumah deret berbentuk kumpulan rumah beserta prasarana, sarana dan utilitas umum. Sehingga pada pasal 15 Undang-Undang No. 1 tahun 2011 disebutkan salah satu tugas pemerintah kabupaten/kota dalam menjalankan fungsi pembinaan yaitu dalam bentuk melaksanakan pengelolaan prasarana, sarana, dan utilitas umum perumahan dan kawasan permukiman. 
Selanjutnya pada pasal 21 No. 1 tahun 2011 tentang perumahan dan kawasan permukiman dijelaskan bahwa jenis rumah terdapat 5 (lima) jenis yaitu;
a. rumah komersial;
b. rumah umum;
c. rumah swadaya;
d. rumah khusus; dan
e. rumah negara.

Sedangkan menurut bentuknya, rumah terbagi menjadi 3 (tiga) jenis, yaitu;
a. rumah tunggal;
b. rumah deret; dan
c. rumah susun.

\section{Perencanaan Prasarana, Sarana dan Utilitas Umum Perumahan}

Prasarana, Sarana dan Utilitas Umum Perumahan merupakan bagian dari perumahan yang harus direncanakan terlebih dahulu oleh pengembang sebelum dilaksanakan pemasaran dan pembangunan perumahan. Dalam rangka untuk menjamin hak setiap warga negara untuk menempati, menikmati, dan/atau memiliki rumah yang layak dalam lingkungan yang sehat, aman, serasi, dan teratur. Maka pemerintah pusat, pemerintah daerah dan/atau setiap orang yang akan merencanakan pembangunan perumahan wajib mendapatkan pengesahan dari pemerinntah daerah terlebih dahulu terkait rencana tapak atau lebih dikenal dengan istilah pengesahan siteplan. Hal ini sesuai dengan amanat Undang-Undang No. 1 tahun 2011 tentang perumahan dan kawasan permukiman pasal 29 ayat 2 yang berbunyi bahwa perencanaan prasarana, sarana, dan utilitas umum yang telah memenuhi persyaratan wajib mendapat pengesahan dari pemerintah daerah. Namun dengan adanya Undang-Undang No. 11 tahun 2020 tentang Cipta Kerja maka pasal 29 dirubah menjadi perencanaan prasarana, sarana dan utilitas umum harus memenuhi standar dan ketentuan standar tersebut diatur melalui peraturan pemerintah yang semula Peraturan Pemerintah Nomor 14 Tahun 2016 menjadi Peraturan Pemerintah Nomor 12 Tahun 2021 tentang Perubahan Peraturan Pemerintah Nomor 14 tahun 2016 tentang Penyelenggaraan Perumahan Dan Kawasan Permukiman. Dalam Peraturan Pemerintah Nomor 12 Tahun 2021 tersebut kini tidak lagi secara eksplisit dinyatakan bahwa perencanaan prasarana, sarana, dan utilitas umum yang telah memenuhi persyaratan wajib mendapat pengesahan dari pemerintah daerah. Tetapi hal tersebut berada pada bagian penjelasan dari pasal 22I ayat 7 huruf a, sehingga jika steakholder yang belum mengetahui perubahan regulasi tersebut maka sangat mungkin akan terjadi kesalahan dalam menafsirkan substansi yang ada dalam perubahan peraturan pemerintah tersebut sehingga membuat pelaksanaan pembangunan perumahan tidak terkendali karena seolah-olah peran pemerintah daerah sudah dikurangi dalam penyelenggaraan pembangunan perumahan.

Perencanaan prasarana, sarana dan utilitas umum perumahan ini dapat dilakukan oleh setiap orang baik orang perseorangan maupun badan hukum. Namun dengan syarat memiliki keahlian perencanaan prasarana, sarana dan utilitas umum perumahan yang 
dibuktikan dengan sertifikat keahlian (SKA) yang syah menurut peraturan perundang undangan. Perencanaan prasarana, sarana dan utilitas umum perumahan tersebut merupakan salah satu jenis kegiatan konstruksi sehingga perencana dipersyaratkan memiliki sertifikat kompetensi kerja sebagai amanat ketentuan yang ada di Undang Undang Nomor 2 tahun 2017 tentang Jasa Konstruksi pasal 70 ayat 1 bahwa setiap tenaga kerja konstruksi yang bekerja di bidang jasa konstruksi wajib memiliki sertifikasi kompetensi kerja.

Perencanaan Prasarana, Sarana dan Utilitas umum perumahan tetap mengakomodir peran serta masyarakat dalam penyelenggaraan Pemerintah Daerah sesuai dengan Undang Undang No. 23 Tahun 2014 tentang Pemerintah Daerah pasal 354 ayat 3 yaitu bentuk partisipasi masyarakat mencakup penyusunan Perda dan kebijakan daerah yang mengatur dan membebani masyarakat, perencanaan, penganggaran, pelaksanaan, pemonitoran, dan pengevaluasian pembangunan daerah, pengelolaan aset dan/atau sumber daya alam daerah dan penyelenggaraan pelayanan publik.

Peran serta masyarakat dalam perencanaan PSU tetap harus mengacu berdasarkan Peraturan perundangan yang berlaku antara lain Peraturan Menteri Perumahan Rakyat Nomor 11 tahun 2008 tentang Pedoman Keserasian Kawasan Perumahan dan Permukiman ditentukan bahwa komposisi lahan di lingkungan perumahan terbagi menjadi dua yaitu lahan efektif dan lahan non efektif. Pada pasal 20 ayat 1 dijelaskan lahan efektif merupakan luas total lahan perpetakan yang digunakan untuk kavling perumahan dan permukiman maupun fasilitas lingkungan yang bersifat komersial dan dapat dijual kepada pihak swasta maupun perorangan sedangkan pada ayat 2 yang dikatakan sebagai lahan non efektif yaitu luas total lahan perpetakan yang digunakan untuk prasarana, sarana, dan utilitas lingkungan perumahan, termasuk fasilitas umum dan fasilitas sosial yang bersifat non komersial, yang sebagian dari lahan non efektif tersebut, sesuai dengan ketentuan yang berlaku, diserahkan kepengelolaannya kepada pemerintah daerah.

Penyediaan prasarana, sarana dan utilitas umum perumahan di Kabupaten Pamekasan minimal adalah $30 \%$ dari luas lahan yang diajukan untuk dijadikan sebagai lingkungan perumahan. Alokasi $30 \%$ tersebut terdiri dari lahan untuk jaringan jalan, jaringan saluran pembuangan air limbah, jaringan saluran pembuangan air hujan (drainase), tempat pembuangan sampah, sarana peribadatan, sarana rekreasi dan olah raga, sarana pertamanan dan ruang terbuka hijau. Sementara untuk sarana pemakaman untuk penghuni lingkungan perumahan dapat bekerja sama dengan pihak desa atau kelurahan setempat yang dituangkan dalam bentuk surat pernyataan kerja sama dengan ditandatangani oleh pengembang dan kepala desa/lurah setempat yang disaksikan oleh perangkat desa atau ketua RT dan RW setempat. 


\section{Implementasi Penyerahan Prasarana, Sarana dan Utilitas Perumahan dan Permukiman}

Kabupaten Pamekasan merupakan salah satu kabupaten yang berada di pulau Madura provinsi Jawa Timur yang merupakan ibu kota karesidenan wilayah Madura. Perkembangan sosial ekonomi dan politik di Kabupaten Pamekasan cenderung sangat dinamis dibanding dengan kabupaten lain yang berada di pulau Madura.

Salah satu sektor ekonomi yang berkembang adalah bidang property. Namun berdasarkan data yang diperoleh dari Dinas Perumahan Rakyat dan Kawasan Permukiman bahwa di kabupaten Pamekasan terdapat 20 (dua puluh) Perumahan baik perumahan umum maupun komersial yang tersebar di beberapa kecamatan dengan rincian seperti dalam tabel berikut:

\section{Tabel 2}

\section{Nama Perumahan Berdasarkan Kecamatan}

\begin{tabular}{lll}
\hline No & \multicolumn{1}{c}{ Nama Perumahan } & $\begin{array}{c}\text { Lokasi } \\
\text { Kecamatan }\end{array}$ \\
\hline 1. & Samatan Asri & Proppo \\
2. & Lakar Nyaman & Pamekasan \\
3. & Tera' Bulan Residence & Tlanakan \\
4. & Citra Indah 2 & Pamekasan \\
5. & Bani Residence & Pademawu \\
6. & Permata Regency & Pamekasan \\
7. & Royal Tambung & Pademawu \\
8. & Grand Nyalaran & Pamekasan \\
9. & Green Village & Pademawu \\
10. & Jokotole Residence & Pademawu \\
11. & Royal Pademawu & Pademawu \\
12. & Royal Residence & Pademawu \\
13. & Royal II Residence & Pademawu \\
14. & Royal Nyalaran & Pamekasan \\
15. & Bazar Residence & Pamekasan \\
16. & Citra Indah 1 & Pamekasan \\
17. & Tlanakan Indah & Tlanakan \\
18. & Graha Kencana & Tlanakan \\
19. & Nyalabu Permai & Pamekasan \\
20. & Bonorogo Permai & Pamekasan \\
\hline
\end{tabular}

Sumber : Dinas Perumahan Rakyat dan Kawasan Permukiman (2021)

Jika ditampilkan dalam bentuk diagram batang dapat ditampilkan sebagai berikut. 


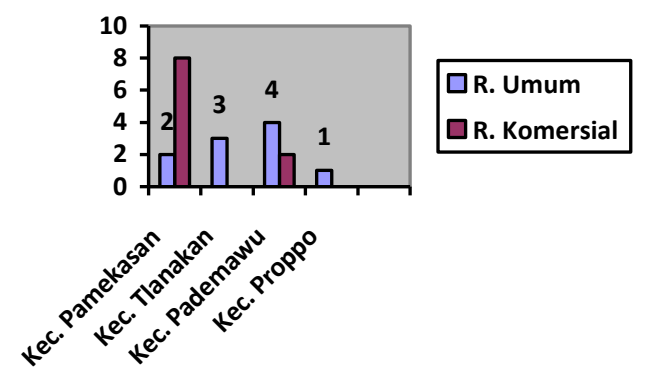

\section{Gambar 1. Diagaram batang rumah umum dan rumah komersial}

Di dalam peraturan menteri dalam negeri nomor 9 tahun 2014 bab II disebutkan bahwa tujuan penyerahan prasarana, sarana, dan utilitas perumahan dan permukiman dari pengembang kepada pemerintah daerah bertujuan untuk menjamin keberlanjutan pemeliharaan dan pengelolaan prasarana, sarana, dan utilitas di lingkungan perumahan dan permukiman.

Sedangkan pada Peraturan Daerah Kabupaten Pamekasan Nomor 7 tahun 2014 tentang Penyerahan Prasarana, Sarana, dan Utilitas Perumahan dan Permukiman pasal 11 ayat 1 Setelah pembangunan prasarana, sarana, dan utilitas perumahan dan permukiman selesai dilaksanakan, pengembang wajib segera menyerahkan kepada Pemerintah Daerah.

Penyerahan Prasarana, Sarana dan Utilitas Umum Perumahan ini dilakukan atas dasar sukarela sesuai dengan pasal 2 ayat 2 Peraturan Presiden Nomor 36 tahun 2005 tentang Pengadaan Tanah Bagi Pelaksanaan Pembangunan Untuk Kepentingan Umum menyatakan bahwa Pengadaan tanah selain bagi pelaksanaan pembangunan untuk kepentingan umum oleh Pemerintah atau pemerintah daerah dilakukan dengan cara jual beli, tukar menukar, atau cara lain yang disepakati secara sukarela oleh pihak-pihak yang bersangkutan. Namun pada peraturan presiden Nomor 71 tahun 2012 tentang Penyelenggaraan Pengadaan Tanah Bagi Pembangunan Untuk Kepentingan Umum dinyatakan bahwa Pelepasan hak adalah kegiatan pcmutusan hubungan hukum dari pihak yang berhak kepada negara melalui BPN. Selanjutnya pada pasal 96 ayat 1 lebih lanjut disebutkan Pelepasan hak Objek Pengadaan Tanah dilaksanakan oleh Pihak yang Berhak kepada negara dihadapan Kepala Kantor Pertanahan setempat dengan dibuatkan berita acara pelepasan hak Objek Pengadaan Tanah.

Prasarana, Sarana dan Utilitas Umum Perumahan dibuat dalam bentuk akta pelepasan hak atas tanah yang dibuat oleh notaris yang biasa dikenal sebagai Akta Pelepasan Hak. Akta Pelepasan Hak atau istilah yang digunakan dalam Peraturan Daerah kabupaten Pamekasan Nomor 7 tahun 2014 yaitu Surat Pelepasan Hak merupakan salah satu syarat yang dibutuhkan dalam proses penyerahan kepada pemerintah daerah hak atas Prasarana, Sarana dan Utilitas Umum Perumahan. Mekanisme pelepasan hak ini harus dilakukan karena status Hak Milik atas tanah hanya dapat dimiliki atau dikuasai oleh perseorangan atau badan hukum. Perseorangan yang dapat memiliki atau menguasai hak atas tanah adalah warga negara Indonesia atau orang 
asing yang berkedudukan di Indonesia. Badan hukum yang dapat memiliki atau menguasai hak atas tanah adalah badan hukum privat atau badan hukum publik, atau badan hukum Indonesia atau badan hukum asing yang mempunyai perwakilan di Indonesia. Salah satu badan hukum yang dapat menguasai hak atas tanah adalah Pemerintah Daerah, yaitu Pemerintah Propinsi, atau Pemerintah Kabupaten/Kota.

Terhadap objek hak atas tanah yang diperlukan oleh Pemerintah Daerah berstatus Hak Milik, maka Pemerintah Daerah tidak dapat memperoleh hak atas tanah yang berstatus Hak Milik melalui jual beli sebab Pemerintah Daerah tidak memenuhi syarat atau bukan sebagai subjek Hak Milik. Objek tanah yang direncanakan untuk dikuasai Pemerintah Daerah tidak dapat dilakukan melalui mekanisme proses jual beli tanah yang berstatus Hak Milik sebab Pemerintah Daerah tidak memenuhi syarat materiil dalam jual beli hak atas tanah. Pemerintah Daerah sebagai pemegang Hak Pakai dan Hak Pengelolaan tidak dapat membeli tanah yang berstatus Hak Milik. Kalau Pemerintah Daerah yang membeli hak atas tanah yang berstatus Hak Milik, maka jual beli hak atas tanah tersebut batal demi hukum, artinya jual beli hak atas tanah tersebut dianggap tidak pernah ada. Hak Milik atas tanah yang dibeli oleh Pemerintah Daerah berakibat Hak Milik atas tanah tersebut menjadi dihapus dan Hak Milik atas tanah kembali menjadi tanah negara atau tanah yang dikuasai langsung oleh negara.

Oleh sebab itu cara perolehan hak atas tanah yang dapat ditempuh oleh Pemerintah Daerah atas tanah yang berstatus Hak Milik, adalah melalui pelepasan Hak Milik atas tanah oleh pemilik tanah. Pelepasan Hak Milik atas tanah didahului oleh musyawarah antara pemilik tanah dan Pemerintah Daerah. Pemilik tanah menyetujui kalau tanahnya diperlukan oleh Pemerintah Daerah. Pelepasan Hak Milik atas tanah oleh pemiliknya dengan atau tanpa pemberian ganti kerugian oleh Pemerintah Daerah. Pelepasan hak atas tanah sebagai cara perolehan hak atas tanah oleh Pemerintah Daerah ditempuh disebabkan Pemerintah Daerah tidak dapat membeli tanah yang berstatus Hak Milik. Pelepasan hak atas tanah oleh pemegang haknya sebagai cara perolehan tanah dalam pengadaan tanah untuk kepentingan umum diatur dalam Undang-Undang No. 2 Tahun 2012 tentang Pengadaan Tanah Bagi Pembangunan untuk Kepentingan Umum, yang dilaksanakan oleh Peraturan Presiden No. 71 Tahun 2012 tentang Penyelenggaraan Pengadaan Tanah Bagi Pembangunan untuk Kepentingan Umum.

Dari 20 (dua puluh) perumahan yang ada di data Dinas Perumahan dan Kawasan Permukiman Kabupaten Pamekasan, sampai saat ini masih 2 (dua) Perumahan yang sudah menyerahkan prasarana, sarana, dan utilitas perumahan. Satu perumahan umum (Perumahan Royal Nyalaran) dan satu lagi perumahan komersil (Citra Indah 2).

Dua perumahan tersebut telah memenuhi persyaratan penyerahan Prasana, Sarana dan Utilitas Umum perumahan sebagaimana diatur dalam ketentuan Peraturan Daerah kabupaten Pamekasan Nomor 7 tahun 2014 pasal 16 yaitu berupa syarat umum, teknis, dan administrasi.

Lebih lanjut dijelaskan apa saja yang dimaksud persyaratan tersebut pada pasal 17 yaitu yang dimaksud dengan persyaratan umum meliputi; lokasi prasarana, sarana, dan utilitas sesuai dengan rencana tapak yang telah disetujui oleh pemerintah daerah; dan 
sesuai dengan dokumen perijinan dan spesifikasi teknis bangunan. Sedangkan persyaratan teknis meliputi; perbandingan antara luas lahan efektif dan non efektif, jaringan jalan, saluran drainase, perhitungan kapasitas layanan fasilitas umum dan fasilitas social. Selanjutnya persyaratan administrasi meliputi; dokumen rencana tapak yang telah disetujui oleh Pemerintah Daerah, izin mendirikan bangunan bagi bangunan yang dipersyaratkan; dan surat pelepasan hak atas tanah dari Pengembang kepada Pemerintah Daerah.

\section{Tabel 3}

Daftar Perumahan dan PSU yang diserahkan pengembang kepada Pemerintah Daerah

\begin{tabular}{llll}
\hline No & $\begin{array}{c}\text { Nama } \\
\text { Perumahan }\end{array}$ & $\begin{array}{c}\text { Jenis PSU yang } \\
\text { diserahkan }\end{array}$ & $\begin{array}{c}\text { Luas } \\
\left(\mathbf{M}^{\mathbf{2}}\right)\end{array}$ \\
\hline 1 & Royal & Jalan & $1.928,66$ \\
& Nyalaran & Taman & 79,94 \\
& & Musholla & 73,40 \\
\hline 2 & Citra Indah & Jalan & $3.516,40$ \\
& 2 & Taman + Musholla & 340,40 \\
& & Saluran & 270,20 \\
& & Pos Satpam + RTH & 776,64 \\
& & TPS & 3,00 \\
\hline
\end{tabular}

Kewajiban Pemerintah Daerah setelah dilakukan penyerahan prasarana sarana dan utilitas umum perumahan adalah pengelolaan. Dalam hal pemeliharaan dan pengembangan prasarana, sarana, dan utilitas, menggunakan dan/atau memanfaatkan prasarana, sarana, dan utilitas, mencatat dan mengubah prasarana, sarana, dan utilitas menjadi asset daerah; dan mengawasi keberadaan prasararta, sarana, dan utilitas.

Pengelolaan prasarana, sarana, dan utilitas yang telah diserahkan kepada Pemerintah Daerah sepenuhnya menjadi tanggung jawab Pemerintah Daerah. Pemerintah Daerah dapat bekerja sama dengan Pengembang, badan usaha swasta dan/atau masyarakat dalam pengelolaan prasarana, sarana, dan utilitas yang diatur.

\section{Kesimpulan}

Sesuai dengan ketentuan UU No. 1 tahun 2011 pasal 1 angka 2 tentang Perumahan dan Kawasan Permukiman bahwa prasarana, sarana, dan utilitas umum sebagai hasil upaya pemenuhan rumah yang layak huni suatu perumahan. Oleh sebab itu untuk tetap menjamin hak hidup yang layak tersebut maka pengembang wajib menyediakan prasarana, sarana, dan utilitas umum yang telah disyahkan oleh Pemerintah Daerah dan dimuat dalam perjanjian pendahuluan jual beli. Selanjutnya setelah konstruksi prasarana, sarana, dan utilitas umum selesai 100\% harus segera diserahkan kepada Pemerintah Daerah paling lama satu tahun setelah masa pemeliharaan oleh pengembang (developer), sesuai pasal 11 ayat 2 huruf a Peraturan Daerah kabupaten Pamekasan Nomor 7 tahun 2014 dengan tetap melengkapi 
Kebijakan dan Implementasi Penyerahan Prasarana, Sarana, dan Utilitas Umum

Perumahan di Kabupaten Pamekasan

persyaratan umum, teknis dan administrasi berdasarkan pasal 14 Peraturan Menteri Dalam Negeri Nomor 9 Tahun 2009 tentang Pedoman Penyerahan Prasarana, Sarana, dan Utilitas Perumahan dan Permukiman di Daerah. 


\section{BIBLIOGRAFI}

Abdul Kadir M., Hukum dan Penelitian Hukum, Bandung, Citra Aditya Bakti, 2004.

Bachtiar, Metode Penelitian Hukum, Unpam Press, Banten, 2019.

Bambang Supriyanto. 2017, Kebijakan Penyerahan Prasarana, Sarana dan Utilitas di Kabupaten Sidoarjo, Jurnal Kebijakan Dan Manajemen Publik. DOI Artikel: 10.21070/jkmp.v5i1.811.

Fitri Intan M., Analisis Kebijakan Publik, AURA, Bandar Lampung, 2017.

Gavin Samir. 2019. Tanggung Gugat Pengembang Kepada Pembeli Akibat Wanprestasi Terhadap Prasarana, Sarana Dan Utilitas Umum Dalam Pelaksanaan Perjanjian Pengikatan Jual Beli Satuan Rumah Susun. Jurnal Perspektif. 24(1), 44-55.

Hayati, S. (2021). Politik Hukum Pertanahan Indonesia. Jakarta: Prenadamedia Group.

Peraturan Daerah Kabupaten Pamekasan Nomor 7 tahun 2014 tentang Penyerahan Prasarana, Sarana, dan Utilitas Perumahan dan Permukiman

Peraturan Pemerintah Nomor 12 Tahun 2021 tentang Penyelenggaraan Perumahan dan Kawasan Permukiman.

Peraturan Pemerintah Nomor 28 Tahun 2020 tentang Perubahan Peraturan Pemerintah Nomor 27 Tahun 2014 tentang Pengelolaan Barang Milik Negara/Daerah;

Sekretariat Jenderal Kemeterian Pekerjaan Umum dan Perumahan Rakyat, Informasi Statistik Pekerjaan umum dan Perumahan Rakyat 2018, Pusat Data dan Teknologi Informasi, Jakarta, 2018.

Sri Hajati, et.al., Politik Hukum Pertanahan Indonesia, Kencana, Jakarta, 2021.

Sri Winarsi, et.al., Seri Hukum Agraria: Prinsip Prioritas dalam Sistem Hukum Agraria Indonesia, Airlangga University Press, Surabaya, 2021.

Sri Winarsi, Wilda Prihatiningtyas, Buku Ajar Pemerintahan Daerah, Airlangga University Press, Surabaya, 2019.

Undang-Undang Dasar Negara Republik Indonesia Tahun 1945.

Undang-Undang Nomor 1 Tahun 2004 tentang Perbendaharaan Negara.

Undang-Undang Nomor 1 Tahun 2011 tentang Perumahan dan Kawasan Permukiman;

Undang-Undang Nomor 23 Tahun 2014 tentang Pemerintahan Daerah;

Undang-Undang Nomor 30 Tahun 2014 tentang Administrasi Pemerintahan; 
Urip Santoso. (2015). "Perolehan Tanah Oleh Pemerintah Daerah Yang Berasal Dari Tanah Hak Milik". Jurnal Perspektif. 20(1), 1-9.

W. Dwi Putro, Herlambang P. Wiratraman. 2015. Penelitian Hukum: Antara yang normative dan Empiris. Epistema Digest 5:3-16.

Y. Awan, Abdoellah dan Rusfiana .Y, Teori dan Analisis Kebijakan Publik, Alfabeta, Bandung, 2016.

\section{Copyright holder:}

Dandy Himawan Sutanto (2021)

First publication right:

Syntax Literate: Jurnal Ilmiah Indonesia

This article is licensed under:

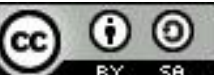

